\title{
Pusat Informasi dan Konseling Remaja: Upaya Perwujudan Pendidikan Nonformal
}

\author{
Akhmad Rofiq \\ Pendidikan Nonformal, Universitas Negeri Yogyakarta \\ Akhmadrofiq@uny.ac.id
}

\begin{abstract}
Abstrak
Penelitian ini bertujuan untuk mengetahui peran Forum Pusat Informasi dan Konseling Remaja (PIK Remaja) sebagai perwujudan pendidikan nonformal di masyarakat. Berkaca pada maraknya perilaku menyimpang di masa remaja saat ini, berbagai kegiatan yang dilaksanakan dari, oleh dan untuk remaja, Forum PIK Remaja memberikan kesempatan bagi remaja untuk memperoleh pengetahuan, kemampuan dan bekal guna menghadapi tantangan kehidupan saat ini. Forum ini memberikan keleluasaan bagi para remaja untuk dapat belajar mengenai penyalahgunaan Napza, Seksualitas, HIV dan Aids serta Life Skill untuk mencapai tujuan program generasi berencana. Kegiatan yang dilaksanakan menjadi pendidikan alternatif bagi kalangan remaja. Metode yang digunakan dalam penelitian ini adalah metode penelitian kualitatif. Oleh karena itu PIK Remaja dapat menjadi pendidikan alternatif para remaja untuk meningkatkan kapasitas remaja dalam menghadapi tantangan kehidupan saat ini.
\end{abstract}

Kata Kunci: pusat informasi dan konseling remaja, remaja, pendidikan nonformal

\begin{abstract}
This study aims to determine the role of the Pusat Informasi dan Konseling Remaja (PIK Remaja) as a manifestation of non-formal education in the community. Reflecting on the prevalence of deviant behavior in adolescence at this time, various activities carried out from, by and for adolescents, the PIK Remaja Forum provides opportunities for adolescents to gain knowledge, abilities and provisions to face the challenges of life today. This forum provides flexibility for young people to be able to learn about drug abuse, sexuality, HIV and AIDS and Life Skills to achieve the goals of the generation planning program. The activities carried out become alternative education for young people. The method used in this study is a qualitative research method. Therefore PIK Remaja can be an alternative education for adolescents to increase the capacity of adolescents in facing life's challenges today.
\end{abstract}

Keywords: pusat informasi dan konseling remaja, adolescent, nonformal education

\section{PENDAHULUAN}

Sebagai wahana belajar remaja, Pusat Informasi dan Konseling Remaja (PIK Remaja) menjadi salah satu solusi strategis untuk menjangkau para remaja di masyarakat. Hal ini dilakukan lantaran saat ini marak perilaku menyimpang para remaja sebagai wujud pencarian jati diri para remaja. Masa remaja merupakan masa pencarian jati diri, mengingat pada usia remaja inilah dimulai untuk dapat dikatakan sebagai pemuda. Di mana pemuda diharapkan oleh khalayak sebagai generasi penerus bangsa. 


\section{Diklus: Jurnal Pendidikan Luar Sekolah, 2 (3), September 2019 - 83 \\ Akhmad Rofiq}

Pemuda adalah simbol dari idealisme, semangat dan cita-cita sebuah bangsa. Pemuda merupakan harapan dan tulang punggung bangsa di masa depan. Sejarah membuktikan bahwa pemuda berperan penting dalam perjuangan bangsa dalam merebut kemerdekaan. Karena pemudalah yang paling bersemangat, ambisius dan berani merombak serta bertindak revolusioner terhadap tatanan sistem kenegaraan. Potensi besar pemuda terletak pada sifat yang cenderung pada pembaruan dan perubahan. Peran pemuda dalam perjalanan sejarah bangsa Indonesia dimulai dari kebangkitan nasional, sumpah pemuda yang menjadi tonggak persatuan Indonesia, perjuangan merebut kemerdekaan Republik Indonesia, tumbangnya orde baru serta lahirnya orde reformasi seluruhnya dimotori oleh pemuda. Meskipun pemuda bukan merupakan satu-satunya agen perubahan, namun pemuda selalu berada pada garda terdepan proses perubahan. Setidaknya ada beberapa pelajaran penting berharga dari sejarah masa lalu gerakan mahasiswa era prareformasi yang bisa dimasukkan wadah kontemplasi kita. Pertama, keberanian, yang oleh Pramoedya Ananta Toer dianggap sebagai unsur paling pokok dalam perjuangan melawan Orba Soeharto, dan menurutnya ini hanya dimiliki oleh pemuda dan mahasiswa. Tanpa keberanian, sepintar apapun kita, tak akan ada yang namanya perubahan(Detik, 2018).

Disamping potensi yang dimiliki pemuda, terdapat juga beberapa permasalahan yang menyangkut pemuda Indonesia. masa muda merupakan tahap kehidupan yang bersifat peralihan dan tidak mantap, sehingga membuat masa muda adalah masa yang rawan oleh pengaruh-pengaruh negative, seperti narkoba, kriminal maupun kejahatan seks. Orang tua maupun masyarakat di lingkungan pemuda yang diharapkan mampu memberikan bentuk pendidikan karakter berbasis masyarakat yang dapat mengarahkan perkembangan pemuda juga tidak mampu melayani pemuda dengan maksimal, sehingga semakin banyak pemuda yang terjerumus dalam berbagai bentuk permasalahan karena kurangnya kemampuan membawa diri.

Berbicara mengenai usia muda, tentu sangat berkaitan dengan masa remaja. Masa remaja merupakan masa peralihan dari anak-anak ke masa dewasa. Kehidupan remaja merupakan kehidupan yang sangat menentukan bagi kehidupan masa depan mereka selanjutnya. Pada tahun 2010 jumlah remaja umur 10-24 tahun sangat besar yaitu sekitar 64 juta atau 27,6\% dari jumlah Penduduk Indonesia sebanyak 237,6 juta jiwa (Sensus Penduduk, 2010). Melihat jumlahnya yang sangat besar, maka remaja sebagai generasi penerus bangsa perlu dipersiapkan menjadi manusia yang sehat secara jasmani, rohani, mental dan spiritual. Faktanya, berbagai penelitian menunjukkan bahwa remaja mempunyai permasalahan yang sangat kompleks seiring dengan masa transisi yang dialami remaja. Kartono (2014, p.45) menyatakan bahwa kenakalan remaja atau disebut juga juvnile delinquency merupakan suatu bentuk gejala patologis pada remaja yang biasanya diakibatkan karena mengabaikan norma sosial, sehingga menimbulkan suatu bentuk prilaku yang menyimpang. Masalah yang menonjol dikalangan remaja yaitu permasalahan seputar TRIAD KRR (Seksualitas, HIV dan AIDS serta Napza), rendahnya pengetahuan remaja tentang Kesehatan Reproduksi Remaja dan median usia kawin pertama perempuan relatif masih rendah yaitu 19,8 tahun. 


\section{Diklus: Jurnal Pendidikan Luar Sekolah, 2 (3), September 2019 - 84 \\ Akhmad Rofiq}

Pada masa remaja manusia tidak dapat disebut sudah dewasa tetapi tidak dapat pula disebut anak-anak. Masa remaja adalah masa peralihan manusia dari anak-anak menuju dewasa. Remaja merupakan masa peralihan antara masa anak dan masa dewasa yang berjalan antara umur 10 tahun sampai 24 tahun. Dalam perkembangan individu selalu terdapat masa muda di mana seorang individu merasa tidak mantap dan cenderung memiliki rasa ingin tahu yang tinggi. Pengertian masa muda adalah suatu tahap kehidupan yang bersifat peralihan dan tidak mantap serta menjadi masa rawan oleh pengaruhpengaruh negatif. Namun harus disadari pula bahwa masa muda adalah masa yang amat baik untuk mengembangkan segala potensi positif yang mereka miliki seperti bakat, minat maupun potensi (Sofyan S. Willis, 2005: 1).

Dalam Kamus Besar Bahasa Indonesia (KBBI) edisi kedua kata pemuda disatupengertiankan dengan remaja yang berarti sudah mulai dewasa dan sudah sampai umur untuk kawin. Sedangkan Salzman dalam Yusuf (2011: 184) mengemukakan bahwa remaja merupakan masa perkembangan sikap tergantung (dependence) terhadap orang tua ke arah kemandirian (independence), minat-minat seksual, perenungan diri, dan perhatian terhadap nilai-nilai estetika dan isu-isu moral.

Sedangkan Harold Albert dalam Syamsuddin (2007: 130) mendefinisikan bahwa masa remaja adalah periode dalam perkembangan yang dijalani seseorang yang terbentang sejak berakhirnya masa kanak-kanak sampai datangnya awal masa dewasa, rentangan masa remaja itu berlangsung sekitar 11-13 tahun sampai 18-20 tahun.

Berdasarkan beberapa pengertian mengenai remaja tersebut, dapat disimpulkan bahwa remaja merupakan masa peralihan dari usia anak menuju dewasa, sehingga dalam perjalanan hidup remaja diiringi berbagai situasi di mana harus menentukan pilihan. Dari hal tersebut tentu usia remaja dikatakan usia rawan mengingat banyak pilihan yang akan menentukan arah kehidupannya, dan tidak jarang pada usia remaja terdapat individu yang tersandung berbagai permasalahan seperti kenakalan remaja, putus sekolah, dan lain sebagainya. Maka dari itu diperlukan wahana untuk mengarahkan dan membimbing individu usia remaja agar lebih berkualitas.

Berdasarkan data dan kondisi tersebut, menunjukkan betapa besarnya jumlah remaja Indonesia yang terganggu kesempatannya untuk melanjutkan sekolah, memasuki dunia kerja, memulai berkeluarga dan menjadi anggota masyarakat secara baik. Sejumlah itu pula remaja yang tidak siap untuk melanjutkan tugas dan peran sebagai generasi penerus bangsa yang diharapkan dapat mengantar Negara Indonesia menjadi Negara berdaulat dan bermartabat. Dengan meningkatnya jumlah remaja yang bermasalah akan mengganggu pencapaian tugas-tugas perkembangan remaja.

Setiap tahap usia manusia pasti ada tugas-tugas perkembangan yang harus dilalui. Bila seseorang gagal melalui tugas perkembangan pada usia yang sebenarnya maka pada tahap perkembangan berikutnya akan terjadi masalah pada diri seseorang tersebut. Tugas-tugas perkembangan pada masa remaja menurut (Hurlock, 2001) antara lain :

a. Mencapai hubungan baru dan yang lebih matang dengan teman sebaya baik pria maupun wanita

Tugas perkembangan pada masa remaja menuntut perubahan besar dalam sikap dan perilaku anak. Akibatnya, hanya sedikit anak laki-laki 


\section{Diklus: Jurnal Pendidikan Luar Sekolah, 2 (3), September 2019 - 85 \\ Akhmad Rofiq}

dan anak perempuan yang dapat diharapkan untuk menguasai tugastugas tersebut selama awal masa remaja, apalagi mereka yang matangnya terlambat. Kebanyakan harapan ditumpukkan pada hal ini adalah bahwa remaja muda akan meletakkan dasar-dasar bagi pembentukan sikap dan pola perilaku.

b. Mencapai peran sosial pria, dan wanita Perkembangan masa remaja yang penting akan menggambarkan seberapa jauh perubahan yang harus dilakukan dan masalah yang timbul dari perubahan itu sendiri. Pada dasarnya, pentingnya menguasai tugastugas perkembangan dalam waktu yang relatif singkat sebagai akibat perubahan usia kematangan yang menjadi delapan belas tahun, menyebabkan banyak tekanan yang menganggu para remaja.

c. Menerima keadaan fisiknya dan menggunakan tubuhnya secara efektif

Seringkali sulit bagi para remaja untuk menerima keadaan fisiknya bila sejak kanak-kanak mereka telah mengagungkan konsep mereka tentang penampilan diri pada waktu dewasa nantinya. Diperlukan waktu untuk memperbaiki konsep ini dan untuk mempelajari cara-cara memperbaiki penampilan diri sehingga lebih sesuai dengan apa yang dicita-citakan.

d. Mengharapkan dan mencapai perilaku sosial yang bertanggung jawab

Menerima peran seks dewasa yang diakui masyarakat tidaklah mempunyai banyak kesulitan bagi laki-laki; mereka telah didorong dan diarahkan sejak awal masa kanak-kanak. Tetapi halnya berbeda bagi anak perempuan. Sebagai anak-anak, mereka diperbolehkan bahkan didorong untuk memainkan peran sederajat, sehingga usaha untuk mempelajari peran feminin dewasa yang diakui masyarakat dan menerima peran tersebut, seringkali merupakan tugas pokok yang memerlukan penyesuaian diri selama bertahun-tahun. Karena adanya pertentangan dengan lawan jenis yang sering berkembang selama akhir masa kanak-kanak dan masa puber, maka mempelajari hubungan baru dengan lawan jenis berarti harus mulai dari nol dengan tujuan untuk mengetahui lawan jenis dan bagaimana harus bergaul dengan mereka. Sedangkan pengembangan hubungan baru yang lebih matang dengan teman sebaya sesama jenis juga tidak mudah.

e. Mencapai kemandirian emosional dari orang tua dan orang-orang dewasa lainnya

Bagi remaja yang sangat mendambakan kemandirian, usaha untuk mandiri secara emosional dari orang tua dan orang-orang dewasa lain merupakan tugas perkembangan yang mudah. Namun, kemandirianemosi tidaklah sama dengan kemandirian perilaku. Banyak remaja yang ingin mandiri, juga ingin dan membutuhkan rasa aman yang diperoleh dari ketergantungan emosi pada orang tua atau orang-orang dewasa lain. Hal ini menonjol pada remaja yang statusnya dalam kelompok sebaya tidak meyakinkan atau yang kurang memiliki hubungan yang akrab dengan anggota kelompok.

f. Mempersiapkan karier ekonomi

Kemandirian ekonomi tidak dapat dicapai sebelum remaja memilih pekerjaan dan mempersiapkan diri untuk bekerja. Kalau remaja memilih pekerjaan yang memerlukan periode pelatihan yang lama, tidak ada jaminan untuk memperoleh kemandirian ekonomi bilamana mereka secara resmi menjadi dewasa nantinya. Secara ekonomi mereka masih harus tergantung selama beberapa tahun sampai pelatihan yang diperlukan untuk bekerja selesai dijalani.

g. Mempersiapkan perkawinan dan keluarga Kecenderungan perkawinan muda menyebabkan persiapan perkawinan merupakan tugas perkembangan yang paling penting dalam tahun- tahun remaja. Meskipun tabu sosial mengenai perilaku seksual yang berangsur-ansur mengendur dapat mempermudah persiapan perkawinan dalam aspek 


\section{Diklus: Jurnal Pendidikan Luar Sekolah, 2 (3), September 2019 - 86 \\ Akhmad Rofiq}

seksual, tetapi aspek perkawinan yang lain hanya sedikit yang dipersiapkan. Kurangnya persiapan ini merupakan salah satu penyebab dari masalah yang tidak terselesaikan, yang oleh remaja dibawa ke masa remaja.

h. Memperoleh perangkat nilai dan sistem etis sebagai pegangan untuk berperilaku mengembangkan ideologi

Sekolah dan pendidikan tinggi mencoba untuk membentuk nilai-nilai yang sesuai dengan nilai dewasa, orang tua berperan banyak dalam perkembangan ini. Namun bila nilai-nilai dewasa bertentangan dengan teman sebaya, masa remaja harus memilih yang terakhir bila mengharap dukungan teman-teman yang menentukan kehidupan sosial mereka. Sebagian remaja ingin diterima oleh teman-temannya, tetapi hal ini seringkali diperoleh dengan perilaku yang oleh orang dewasa dianggap tidak bertanggung jawab.

Melihat kenyaatan tersebut dan dalam rangka mengemban amanat undangundang serta merespon permasalahan remaja, BKKBN mengembangkan Program Generasi Berencana (GenRe) bagi Remaja dan keluarga yang memiliki remaja yang sesuai dengan Tugas Pokok dan Fungsinya dilaksanakan oleh Direktorat Bina Ketahanan Remaja (Dithanrem). Program ini didasarkan pada Peraturan Kepala Badan Koordinasi Keluarga Berencana Nasional Nomor 47/HK.010/B5/2010 tentang Rencana Strategis Badan Koordinasi Keluarga Berencana Nasional 2010 - 2014 dan Addendum Peraturan Kepala Badan Kependudukan dan Keluarga Berencana Nomor 133/PER/B1/2011 tentang Rencana Strategis Badan Kependudukan dan Keluarga Berencana Tahun 2010 -2014 untuk Pembangunan Kependudukan dan Keluarga Berencana. Dalam adendum tersebut dinyatakan sebagai berikut: a. Meningkatnya usia kawin pertama (UKP) perempuan dari 19.8 (SDKI 2007) menjadi sekitar 21 tahun.

b. Meningkatnya partisipasi keluarga yang mempunyai anak dan remaja dalam kegiatan kelompok kegiatan Bina Keluarga Remaja (BKR) dari 1.5 juta menjadi 2.7 juta keluarga remaja.

Program GenRe tersebut dilaksanakan berkaitan dengan bidang kehidupan yang kelima dari transisi kehidupan remaja dimaksud, yakni mempraktikkan hidup secara sehat (practice healthy life). Empat bidang kehidupan lainnya yang akan dimasuki oleh remaja sangat ditentukan oleh berhasil tidaknya remaja mempraktikkan kehidupan yang sehat. Dengan kata lain apabila remaja gagal berperilaku sehat, kemungkinan besar remaja yang bersangkutan akan gagal pada empat bidang kehidupan yang lain. Program GenRe ditujukan kepada remaja/mahasiswa melalui wadah PIK Remaja/Mahasiswa (PIK R/M) dan keluarga yang memiliki remaja melalui wadah Bina Keluarga Remaja (BKR).

PIK Remaja/Mahasiswa adalah salah satu wadah yang dikembangkan dalam program GenRe, yang dikelola dari, oleh dan untuk Remaja/Mahasiswa guna memberikan pelayanan informasi dan konseling tentang pendewasaan usia perkawinan, delapan fungsi keluarga, TRIAD KRR (seksualitas, HIV dan AIDS serta Napza), keterampilan hidup (life skills), gender dan keterampilan advokasi dan KIE. Keberadaan dan peranan PIK R/M dilingkungan remaja/ mahasiswa sangat penting artinya dalam membantu remaja/mahasiswa untuk memperoleh informasi dan pelayanan konseling yang cukup dan benar tentang penyiapan kehidupan berkeluarga bagi remaja/mahasiswa.

Pusat Informasi dan Konseling Remaja (PIK Remaja) adalah suatu 


\section{Diklus: Jurnal Pendidikan Luar Sekolah, 2 (3), September 2019 - 87 \\ Akhmad Rofiq}

wadah kegiatan program Penyiapan Kehidupan Berkeluarga Bagi Remaja (PKBR) yang dikelola dari, oleh, dan untuk remaja guna memberikan pelayanan informasi dan konseling tentang Penyiapan Kehidupan Berkeluarga Bagi Remaja serta kegiatankegiatan penunjang lainnya. PIK Remaja adalah nama generik. Untuk menampung program PKBR dan menarik minat remaja datang ke PIK Remaja, nma generik ini dapat dikembangakan dengan nama-nama yang sesuai dengan kebutuhan program dan selere remaja setempat. Program ini bertujuan untuk meningkatkan akses dan kualitas pengelolaan dan pelayanan PIK Remaja dalam rangka peningkatan pencapaian tujuan PIK Remaja. Sedangkan tujuan dari PIK Remaja itu sendiri adalah untuk memberikan informasi PKBR, Pendewasaan Usia Perkawinan, Keterampilan Hidup (Life Skills), pelayanan konseling dan rujukan PKBR. Disamping itu untuk mengembangkan kegiatan-kegiatan lain yang khas, sesuai dengan minat dan kebutuhan remaja untuk mencapai Tegar Remaja dalam rangka Tegar Keluarga guna mewujudkan Keluarga Kecil Bahagia Sejahtera (BKKBN, 2012).

Ruang lingkup Pusat Informasi dan Konseling Remaja meliputi aspek-aspek kegiatan pemberian informasi PKBR (Penyiapan Kehidupan Berkeluarga bagi Remaja), PUP (Pendewasaan Usia Perkawinan), Keterampilan Hidup (Life Skills), pelayanan konseling, rujukan, pengembangan jaringan dan dukungan, dan kegiatan-kegiatan pendukung lainnya sesuai dengan ciri dan minat remaja. Selain itu juga PIK Remaja tidak mengikuti wilayah administrasi seperti tingkat desa, tingkat kecamatan, tingkat kabupaten/kota atau propinsi. Artinya PIK Remaja dapat melayani remaja lainnya yang berada di luar lokasi wilayah administrasinya. PIK Remaja dalam penyebutannya bisa dikaitkan dengan tempat dan institusi pembinanya seperti PIK Remaja sekolah, PIK Remaja masjid, PIK Remaja pesantren, dan lainlain.

PIK Remaja merupakan salah satu dari sekian banyak program Generasi Berencana (GenRe) dari BKKBN yang dikelola dari, oleh dan untuk remaja. Sehingga memiliki peran yang strategis sebagai wahana belajar dalam peningkatan kualitas remaja serta mampu menghadapi tantangan kehidupan remaja saat ini yang semakin komplek. Dalam kehidupan remaja, walaupun orang tua tetap memberi pengaruh utama dalam sebagian besar kehidupan, bagi sebagian besar remaja, teman sebaya dianggap lebih berperan penting ketika masa remaja dibandingkan masa kanakkanak. Kelompok teman sebaya memberikan remaja perasaan kekuatan dan kekuasaan. Oleh karena itu PIK R melalui Pendidik Sebaya dan Konselor Sebaya memiliki peran strategis bagi remaja untuk mengembangkan dirinya ke arah kegiatan yang positif.

Keberadaan Forum Pusat Informasi dan Konseling Remaja Tunas Sembada di Kabupaten Sleman memiliki peran strategis dalam proses pencapaian pelayanan kepada masyarakat khususnya remaja secara luas. Hal ini perlu dilakukan agar kualitas sumber daya manusia dapat menjadi lebih baik dengan pola kehidupan yang jauh dari keterbelakangan serta memiliki pengetahuan dan wawasan yang lebih mengenai PKBR, pendewasaan usia perkawinan, delapan fungsi keluarga, TRIAD KRR (seksualitas, HIV dan AIDS serta Napza), keterampilan hidup (life skills), gender dan keterampilan advokasi dan KIE sehingga menjadi agen 


\section{Diklus: Jurnal Pendidikan Luar Sekolah, 2 (3), September 2019 - 88 \\ Akhmad Rofiq}

ataupun pendidik/konselor sebaya serta dapat memenuhi tugas-tugas pertumbuhan dan perkembangan remaja baik secara individual, yaitu pertumbuhan fisik, perkembangan mental, emosional dan spiritual serta sosialnya.

Dari berbagai kegiatan yang telah dilaksanakan ini membuat peneliti tertarik untuk mengetahui lebih mendalam mengenai detail bentuk pendidikan nonformal yang diselenggarakan forum Pusat Informasi dan Konseling Remaja ini. Khususnya dalam pola pembinaan remaja menghadapi tantangan kehidupan saat ini.

\section{METODE}

Jenis penelitian yang digunakan dalam penelitian ini adalah deskriptif kualitatif. Penelitian kualitatif ini merupakan penelitian yang dimaksudkan untuk mengungkapkan gejala secara holistic-kontekstual melalui pengumpulan data dari latar alami dengan memanfaatkan diri peneliti sebagai instrumen kunci. Penelitian kualitatif bersifat deskriptif dan cenderung menggunakan analisis dengan pendekatan induktif. Proses dan makna (perspektif subyek) lebih ditonjolkan dalam penelitian kualitatif.

Penelitian ini dilakukan di Forum Pusat Informasi dan Konseling Remaja Tunas Sembada Kabupaten Sleman, yang menaungi 17 PIK R di Kabupaten Sleman. Peneliti memilih penelitian ini karena Forum PIK R Tunas Sembada telah melaksanakan berbagai kegiatan sebagai wahana belajar bagi para remaja di sekitarnya. Sedangkan untuk mendapatkan data yang lengkap mengenai kegiatan Forum PIK R Tunas Sembada, peneliti melakukan berbagai teknik pengumpulan data seperti wawancara, observasi, serta dokumentasi.

Metode analisis yang digunakan dalam penelitian ini adalah teknik analisis kualitatif dengan metode deskriptif. Aktivitas dalam analisis data, yaitu: data reduction, data display, and data conclusion drawing verification (Miles dan Huberman yang dikutip Sugiyono, 2011: 246). Reduksi data adalah kegiatan mengabstraksi atau merangkum data dalam suatu laporan yang sistematis dan difokuskan pada hal-hal yang inti (Sudjana, 2006:214). Setelah direduksi, data akan memberikan gambaran yang lebih tajam mengenai hasil penelitian dan mempermudah peneliti dalam mencari data yang masih diperlukan. Dengan mereduksi data dapat memperoleh gambaran yang lebih jelas dari data yang telah diperoleh dan mempermudah peneliti untuk melakukan pengumpulan data selanjutnya dan mencarinya apabila diperlukan. Display data adalah proses penyampaian informasi tersusun yang memberikan kemungkinan adanya penarikan kesimpulan dan pengambilan tindakan. Hasil dari reduksi data disajikan dalam bentuk laporan secara keseluruhan maupun bagian-bagiannya. Verifikasi data yaitu melakukan pencarian makna dari katakata yang dikumpulkan secara lebih teliti.. Kesimpulan yang telah dibuat sebelumnya yang masih bersifat sementara akan berubah bila ditemukan bukti-bukti pendukung yang kuat pada tahap pengumpulan data selanjutnya. Hasil dari verifikasi data adalah kesimpulan secara utuh, menyeluruh, dan akurat. Sedangkan Trianggulasi yang digunakan dalam penelitian ini adalah trianggulasi dengan sumber data yang berbeda, yang tersedia di lapangan. Melalui teknik ini peneliti mengecek keabsahan data yang diperoleh melalui 


\section{Diklus: Jurnal Pendidikan Luar Sekolah, 2 (3), September 2019 - 89 \\ Akhmad Rofiq}

cross check yaitu membandingkan data yang diperoleh dari wawancara dan data pengamatan, maka dapat di simpulkan bahwa ada permasalahan yang perlu ditinjau kembali atau diadakan cek ulang.

\section{HASIL DAN PEMBAHASAN}

Masa remaja merupakan tahap kehidupan yang bersifat peralihan dan tidak mantap, sehingga membuat masa remaja adalah masa yang rawan oleh pengaruh-pengaruh negatif, seperti narkoba, kriminal maupun kejahatan seks. Orang tua maupun masyarakat di lingkungan pemuda yang diharapkan mampu memberikan bentuk pendidikan karakter berbasis masyarakat yang dapat mengarahkan perkembangan pemuda juga tidak mampu melayani pemuda dengan maksimal, sehingga semakin banyak pemuda yang terjerumus dalam berbagai bentuk permasalahan karena kurangnya kemampuan membawa diri.

Para remaja sekarang terjebak dengan mind set pragmatisme dan jauh dari semangat perjuangan yang terbungkus oleh idealisme yang bertujuan untuk menciptakan umat dan bangsa yang memiliki martabat dan mandiri. Sehingga memunculkan berbagai permasalahan seperti pengangguran yang terus meningkat, kenakalan remaja seperti tindak kriminalitas, pemakaian narkoba, seks bebas, maupun kenalakan lainnya yang merugikan masyarakat itu sendiri. Hal tersebut juga menandakan kurang adanya penekanan untuk mengendalikan dirinya sendiri, sehingga secara tidak langsung mendorong tindakan negatif itu muncul.

Pusat Informasi dan Konseling Remaja merupakan salah satu strategi guna mewujudkan program generasi berencanan yang telah dilaksanakan. Menerapkan konsep dari, oleh dan untuk remaja, PIK Remaja berupaya untuk menjadi wahana belajar para remaja. Hal ini seperti yang telah dilaksanakan oleh Forum PIK Remaja Tunas Sembada di Kabupaten Sleman, yang mana dalam rutinitasnya selalu menyelenggarakan kegiatan yang bertujuan untuk meningkatkan kualitas para remaja di Kabupaten Sleman sehingga mampu menghadapi tantangan maupun ancaman masa remaja yang sangat rawan dari hal-hal negatif. Pengelola PIK Remaja adalah pemuda/remaja yang punya komitmen dan mengelola langsung PIK Remaja serta telah mengikuti pelatihan dengan mempergunakan modul dan kurikulum standar yang telah disusun oleh BKKBN atau yang sejenis. Pengelola PIK Remaja terdiri dari Ketua, Bidang Administrasi, Bidang Program dan Kegiatan, Pendidik Sebaya dan Konselor Sebaya.

Sedangkan untuk ruang lingkup PIK Remaja meliputi aspek-aspek kegiatan pemberian informasi PKBR (Penyiapan Kehidupan Berkeluarga bagi Remaja), PUP (Pendewasaan Usia Perkawinan), Keterampilan Hidup (Life Skills), pelayanan konseling, rujukan, pengembangan jaringan dan dukungan, dan kegiatan-kegiatan pendukung lainnya sesuai dengan ciri dan minat remaja. Hal ini seperti karakteristik pendidikan nonformal dalam segi proses belajar yakni berkaitan dengan kehidupan peserta didik dan masyarakat, pada waktu mengikuti program peserta berada dalam dunia kehidupan dan pekerjaannya, lingkungan dihubungkan secara fungsional dengan kegiatan belajar (Abdul Rahmat, 2018, p.11).

Selain itu juga PIK Remaja tidak mengikuti wilayah administrasi seperti tingkat desa, tingkat kecamatan, tingkat kabupaten/kota atau propinsi. Artinya PIK Remaja dapat melayani remaja lainnya yang berada di luar lokasi 


\section{Diklus: Jurnal Pendidikan Luar Sekolah, 2 (3), September 2019 - 90 \\ Akhmad Rofiq}

wilayah administrasinya. PIK Remaja dalam penyebutannya bisa dikaitkan dengan tempat dan institusi pembinanya seperti PIK Remaja sekolah, PIK Remaja masjid, PIK Remaja pesantren, dan lainlain. Sehingga pelayanan PIK Remaja tidak terkekang dalam batas administrasi tertentu yang dapat menjangkau ke masyarakat dengan lebih mudah tanpa batasan tersebut.

Guna mendukung program Generasi Berencana yang dicanangkan, Forum PIK Remaja Tunas Sembada memiliki beberapa kegiatan sebagai wahana belajar bagi para remaja. Adapun beberapa kegiatan yang tersusun dalam program Forum PIK Remaja Tunas Sembada adalah sebagai berikut:

a. Jambore Forum PIK R

Merupakan program jangka panjang yang dilakukan setiap tiga tahun sekali. Program ini bertujuan untuk mengumpulkan kaderkader pendidik dan konselor sebaya se Kabupaten Sleman guna membentuk kepengurusan baru serta pelaporan program kerja yang telah dilaksanakan.

b. Pelatihan PSKS

Merupakan program yang dilakukan setiap satu tahun sekali. Program ini bertujuan untuk meningkatkan kualitas kader-kader pendidik dan konselor sebaya melalui kegiatan pelatihan yang dirancang selama tiga hari dua malam di tempat tertentu. Kuota untuk program ini untuk sekitar 150 kader pendidik dan konselor sebaya setiap tahunnya, dengan rincian tujuh sampai sembilan kader per kecamatan. Program ini merupakan program unggulan dari Forum PIK R Kabupaten Sleman yang diadakan pada medio bulan September tiap tahunnya.

c. Studi Banding

Merupakan program yang dilakukan setiap satu tahun sekali. Program ini bertujuan untuk memberikan tambahan pengetahuan dan wawasan kepada kaderkader pendidik dan konselor sebaya terkait kegiatan sosialisasi, penanganan, dan rehabilisasi masalah-masalah yang menjadi bidang garapan PIK R. Peserta program ini sangat terbatas, sehingga diperlukan kriteria-kriteria tertentu untuk mengikuti program ini. Untuk tahun ini, program studi banding telah dilaksanakan dengan menimba ilmu di salah satu PIK Remaja di Kabupaten Malang.

d. Gathering

Merupakan program yang dilakukan setiap tiga bulan sekali atau triwulan. Program ini bertujuan untuk meningkatkan solidaritas, pengetahuan dan wawasan kepada kader-kader pendidik dan konselor sebaya melalui kegiatan fun games, ramah tamah, diskusi dan lain sebagainya. Program ini dilakukan secara bergilir dari kecamatan satu ke kecamatan lain untuk meningkatkan solidaritas kader antar kecamatan. Melalui program ini dilaksanakan laporan kegiatan masing-masing PIK R Kecamatan, sehingga ada bentuk evaluasi formatif yang dilakukan untuk pengendalian dan pengarahan kegiatan PIK R Kecamatan.

e. Konsolidasi

Merupakan program yang dilakukan setiap satu bulan sekali. Program ini bertujuan untuk mengetahui kegiatan yang telah maupun akan dilaksanakan PIK $\mathrm{R}$ Kecamatan. Dalam kesempatan ini dilakukan pelaporan-pelaporan mengenai kendala-kendala yang dihadapi di Kecamatan. Program ini juga sebagai wujud bentuk evaluasi formatif lembaga untuk meningkatkan kualitas dan arah layanan yang diberikan PIK R.

f. Micro Teaching

Merupakan program yang dilakukan setiap satu bulan sekali. Program ini bertujuan untuk meningkatkan keterampilan kader pendidik dan konselor sebaya dalam penyampaian materi. Program ini berisikan diskusi masalah, praktek penyampaian materi dan juga penentuan materi sosialisasi. Dalam pelaksanaan program ini diserahkan langsung kepada masing-masing kecamatan dengan pendampingan langsung dari penanggung jawab kecamatan dari kabupaten untuk pengarahan kegiatan program.

\section{g. Sosialisasi GenRe}

Merupakan program yang dilakukan minimal satu bulan sekali. Di mana setiap bulannya PIK R kecamatan telah memiliki sasaran wajib untuk kegiatan sosialisasi seperti karang taruna, PKK, sekolah dan lain 


\section{Diklus: Jurnal Pendidikan Luar Sekolah, 2 (3), September 2019 - 91 \\ Akhmad Rofiq}

sebagainya, akan tetapi jika terdapat lembaga yang meminta untuk sosialisasi akan dilaksanakan program ini. Program ini bertujuan untuk memberikan pengetahuan dan wawasan terkait apa itu PIK R, bidang garapan PIK $\mathrm{R}$, serta penyadaran kepada masyarakat khususnya remaja terkait permasalahan yang dihadapinya dengan penyampaian materi maupun pendampingan yang dilakukan oleh kader pendidik dan konselor sebaya.

h. Pemberdayaan GenRe

Merupakan program yang dilakukan oleh masing-masing PIK $\mathrm{R}$ kecamatan sesuai dengan potensi masing-masing wilayah. Program ini merupakan follow up dari garapan PIK $\mathrm{R}$ yaitu life skill di mana berbentuk pemberdayaan kreativitas, pemberdayaan kesenian dan budaya, pemberdayaan kesehatan, dan lain sebagainya. Bentuk kegiatan dari program ini adalah kegiatan daur ulang bahan bekas, pembuatan souvenir, kesenian tari, rebana, dan lain sebagainya. Program ini bertujuan untuk memberikan keterampilan hidup serta meningkatkan minat dan bakat remaja, sehingga arah kegiatan remaja lebih positif dan meminimalisir kegiatan yang mengarah ke hal negatif.

i. Rekruitmen GenRe

Merupakan program yang dilakukan untuk menambah kuantitas anggota kader PIK R. Di mana dari anggota baru tersebutlah yang akan diikutkan program Pelatihan PSKS untuk dijadikan kader pendidik dan konselor sebaya. Untuk menjadi anggota PIK $\mathrm{R}$ tidak memerlukan persyaratan khusus melainkan diutamakan bagi remaja yang mau dan mampu untuk bergerak di bidang sosial mendukung program Generasi Berencana.

Beberapa program yang dijalankan Forum PIK Remaja Tunas Sembada ini pada dasarnya guna memfasilitasi para remaja untuk belajar mengenai Seksualitas, Napza, HIV dan Aids, serta life skills. Sehingga dengan belajar mengenai beberapa aspek tersebut para remaja mendapat bekal yang cukup dalam menghadapi dampak negatif dari perkembangan kehidupan saat ini. Kegiatan yang dilaksanakan dalam program PIK Remaja ini sangat mendukung fungsi pendidikan nonformal yaitu sebagai pendidikan alternatif, mengingat kegiatan tersebut tidak didapatkan melalui pendidikan formal. Pendidikan nonformal adalah setiap kesempatan dimana terdapat komunikasi yang teratur dan terarah di luar sekolah, dan seseorang memperoleh informasi, pengetahuan dan latihan maupun bimbingan sesuai dengan usia dan kebutuhan hidupnya dengan tujuan mengembangkan tingkat keterampilan, sikap dan nilai-nilai yang memungkinkan baginya menjadi peserta yang efisien dan efektif dalam lingkungan keluarganya bahkan masyarakatnya dan negaranya (Saleh Marzuki, 2009, p.136). Merujuk pada pernyataan tersebut, menunjukkan bahwa Pusat Informasi dan Konseling Remaja dapat dinyatakan sebagai perwujudan pendidikan nonformal yang ada di masyarakat. Mengingat pengertian lembaga PNF sejenis adalah lembaga pendidikan yang tumbuh dan berkembang di masyarakat, yang memberikan pelayanan pendidikan nonformal berorientasi life skills/keterampilan (Abdul Rahmat, 2018, p.14).

Demi tercapainya tujuan dari berbagai program yang dimiliki, Forum PIK Remaja juga bermitra dengan berbagai instansi terkait, sehingga apa yang dilaksanakan benar-benar sesuai dengan tujuan pelaksanaan program. Adapun mitra forum PIK R Tunas Sembada antara lain sebagai berikut:

a. Dinas Kesehatan Kabupaten Sleman

b. Dinas Pendidikan Kabupaten Sleman

c. Badan Narkotika Nasional Kabupaten Sleman (BNNK)

d. Kepolisian (Polres Sleman)

e. Pusat Informasi dan Konseling Mahasiswa (UPN, UMY, STIKES, UIN, UGM, UII)

Sinergitas yang dijalin Forum PIK Remaja Tunas Sembada dengan beberapa mitra tersebut tentunya menambah fasilitas bagi para remaja untuk aktif belajar di berbagai kegiatan yang dilaksanakan. Sebagai wahana belajar remaja Forum PIK Remaja tentunya memberikan bekal positif bagi para remaja khususnya dalam hal Seksualitas, Napza, HIV dan Aids serta Life 


\section{Diklus: Jurnal Pendidikan Luar Sekolah, 2 (3), September 2019 - 92}

Akhmad Rofiq

Skills, sehingga apa yang diperoleh dari kegiatan yang dilaksanakan akan menjadi stimulan bagi remaja lain melalui peran remaja sebagai Pendidik Sebaya maupun Konselor sebaya yang memberikan ruang strategis bagi remaja untuk mengantisipasi tantangan remaja saat ini.

\section{SIMPULAN}

Forum PIK Remaja memiliki peran strategis sebagai wahana belajar para remaja dalam menghadapi tantangan zaman saat ini. Mengingat saat ini, marak terjadi perilaku menyimpang yang dilakukan oleh para remaja. Maka dari itu Forum PIK Remaja memiliki peran strategis untuk melakukan pembinaan dan pemberdayaan remaja mengingat berbagai kegiatan yang yang dilakukan lebih dekat kepada remaja di masyarakat. Kegiatan yang dijalankan sebagai bentuk pembinaan dan pemberdayaan remaja merupakan perwujudan pendidikan nonformal sebagai bentuk pendidikan alternatif di masyarakat yang dapat dimanfaatkan para remaja untuk wahana belajar para remaja. Sebagai wahana belajar para remaja PIK Remaja memberikan keleluasaan bagi remaja dalam mengembangkan diri dalam hal pengetahuan tentang Seksualitas, Napza, HIV dan Aids serta Life Skill. Selain itu keberadaan mitra Forum PIK $\mathrm{R}$ juga memberikan jaminan tentang materi yang ada dalam setiap kegiatannya. Dari berbagai kegiatan yang laksanakan tersebut tentunya Forum PIK Remaja sebagai perwujudan pendidikan nonformal mampu memberikan kontribusi positif guna mendukung tercapainya program generasi berencana yang telah dicanangkan pemerintah.

\section{DAFTAR PUSTAKA}

Abdul Rahmat. 2018. Manajemen Pemberdayaan Pada Pendidikan
Nonformal. Gorontalo: Ideas Publishing.

Azis Syamsudin. 2008. Kaum Muda Menatap Masa Depan Indonesia. Jakarta: RMBOOKS.

BKKBN. 2012. Panduan Pengelolan: Pusat Informasi dan Konseling Remaja dan Mahasiswa (PIK R/M). Jakarta: Direktorat Ketahanan Remaja.

BKKBN DIY. 2010. Panduan Pengelolaan: Pusat Informasi dan Konseling Remaja (PIK Remaja). Yogyakarta: BKKBN DIY.

Detik. 2018. 20 Tahun Reformasi, Menarik Benang Esensi Gerakan Mahasiswa. (21 Mei 2018). Diakses dari

https://news.detik.com/kolom/d4032301/20-tahun-reformasimenarik-benang-esensi-gerakanmahasiswa.

Didin dan Imam. 2013. Manajemen Pendidikan Konsep Dan Prinsip Pengelolaan Pendidikan. Yogyakarta: Ar-ruzz Media.

Kartono, K. (2014). Psikologi Sosial 2 Kenakalan Remaja (ediz ed). Jakarta: PT Rajawali Pers.

Kedaulatan Rakyat. 2013. Kenakalan Remaja Mulai Ke Kriminalitas. Kedaulatan Rakyat (8 Februari 2013). Hlm.6.

Kemenpora. 2010. Penyajian Data dan Informasi Statistik Kepemudaan Tahun 2010. Jakarta: Kemenpora RI.

Moleong, L.J. 2011. Metodologi Penelitian Kualitatif. Bandung: PT Remaja Rosda Karya.

Nurul Zuriah. 2007. Metodologi Penelitian Sosial Dan Pendidikan. Jakarta: PT. Bumi Aksara.

Saleh Marzuki. 2009. Dimensi-dimensi Pendidikan Nonformal. Malang: UNM Press.

Sofyan S. Willis. 2005. Remaja Dan Masalahnya. Bandung: Alfabeta. 
Diklus: Jurnal Pendidikan Luar Sekolah, 2 (3), September 2019 - 93

Akhmad Rofiq

Sugiyono. 2011. Metode Penelitian

Pendidikan Pendekatan Kuantitatif,

Kualitatif, dan R\&D. Bandung:

Alfabeta. 